\title{
Framework CodeIgniter pada Rancang Bangun Prili (Primakara Library)
}

\author{
I Wayan Darma Yasa ${ }^{1}$, I Putu Satwika², \\ Eka Grana Aristyana Dewi ${ }^{3}$, Ni Luh Putu Ning Septyarini Putri Astawa ${ }^{4}$ \\ Program Studi Sistem Informasi, STMIK Primakara, Indonesia ${ }^{1,4}$ \\ Program Studi Teknik Informatika, STMIK Primakara, Indonesia ${ }^{2}$ \\ Program Studi Sistem Informasi Akuntansi, STMIK Primakara, \\ Indonesia ${ }^{3}$ \\ Email corresponding author: yasa13darma@gmail.com
}

\begin{abstract}
ABSTRAK
Perpustakaan Digital adalah suatu perpustkaan yang memanfaatkan teknologi informasi untuk pengelolaan koleksi pustaka ataupun setiap kegiatan perpustakaan. Digitalisasi perpustakaan merupakan suatau keharusan bagi setiap Perguruan Tinggi karena hal tersebut dijelaskan pada Pasal 24 Ayat (3) UU Nomor 43 Tahun 2007. Selain itu perpustakaan digital juga diperlukan ketika Perguruan Tinggi melaksanakan akreditasi Perguruan Tinggi. Namun pada STMIK Primakara, sistem perpustakaan digital yang ada belum mampu memenuhi seluruh data seperti statistik kunjungan yang diperlukan pada saat akreditasi. Untuk mengatasi masalah tersebut, maka dibangun sistem yang dapat mendukung hal tersebut. Penelitian ini menggunakan metode Personal Extreme Programming (PXP) serta menggunakan Framework CodeIgniter sebagai pondasi sistem dan pada uji efektivitas sistem menggunakan metode McLean and DeLone. Penelitian ini berhasil membangun dan mengimplementasikan sistem perpustakaan digital yang telah dirancang. Dari hasil uji efektivitas sistem yang dilakukan dengan menyebar kuisioner kepada mahasiswa STMIK Primakara, dapat dikatakan bahwa sistem yang telah dibangun mendapatkan hasil yang sudah cukup baik pada hampir tiap variabel uji efektivitasnya
\end{abstract}

Kata kunci: Perpustakaan Digital, CodeIgniter, Personal Extreme Programming

\section{PENDAHULUAN}

Perpustakaan menurut UU Nomor 43 Tahun 2007 adalah "institusi pengelola koleksi karya tulis, karya cetak, dan/atau karya rekam secara profesional dengan sistem yang baku guna memenuhi kebutuhan pendidikan, penelitian, pelestarian, informasi, dan rekreasi para pemustaka" (Indonesia, 2007). Sedangkan Perpustakaan Digital adalah suatu perpustkaan yang memanfaatkan teknologi 
informasi untuk pengelolaan koleksi pustaka ataupun setiap kegiatan perpustakaan. Digitalisasi perpustakaan merupakan suatau keharusan bagi setiap Perguruan Tinggi karena hal tersebut dijelaskan pada Pasal 24 Ayat (3) UU Nomor 43 Tahun 2007 yang berbunyi "Perpustakaan perguruan tinggi mengembangkan layanan perpustakaan berbasis teknologi informasi dan komunikasi".

Selain karena sudah diatur oleh Undang-Undang, digitalisasi perpustakaan dapat memberikan banyak manfaat dan dapat menjangkau lebih banyak orang agar dapat mengakses koleksi pustaka perpustakaan kapan saja dan dimana saja. Seperti yang telah dijabarkan pada penelitian-penelitian yang sebelumnya.

Pada penelitian yang berjudul "Perancangan Sistem Perpustakaan Online Menggunakan Metode Model View Controller (MVC) Studi Kasus STMIK Asia Malang" menghasilkan bahwa aplikasi perpustakaan online menggunakan model MVC disimpulkan website yang dibangun dapat membantu daya akses mahasiswa semakin luas, serta mampu memenuhi kebutuhan informasi yang bersifat dinamis. Selain itu informasi yang disampaikan sudah memenuhi kebutuhan para pengguna mengenai rincian buku, daftar peminjaman, daftar denda, stok buku, ketersediaan buku, dan akses peminjaman buku (Putri \& S, 2016).

Pernyataan tersebut didukung juga oleh penelitian yang berjudul "Analisa dan Perancangan Sistem Informasi Perpustakaan" yang menyatakan bahwa sistem yang dibuat dapat digunakan untuk memberikan informasi kepada pihak-pihak terkait mengenai bahan pustaka yang dimiliki beserta kondisinya secara akurat dan lengkap (Nugraha, 2014). Selain itu pada penelitian yang berjudul "Sistem Informasi Perpustakaan Online (E-Library) Pada MTs AL Maghfiroh Pekayon" juga menghasilkan pernyataan yang sama, yaitu sistem mempermudah anggota memperoleh data dan meminjam buku perpustakaan yang diinginkan secara cepat sedangkan bagi pustakawan dapat memudahkan dalam pengelolaan dan pelaporan data perpustakaan (Budihartanti, Tuslaela, \& Aeni, 2019).

Lebih jauh lagi, penelitian yang berjudul "Pengembangan Perpustakaan Digital Berbasis Android Dengan Metode Scrum" menghasilkan bahwa sistem yang dibuat dapat memudahkan anggota mengetahui koleksi buku perpustakaan serta efisiensi waktu untuk mencari koleksi buku (Wahyudi, 2018). Melanjutkan pernyataan diatas, pada penelitian yang berjudul "Perancangan Dan Pengembangan Sistem Informasi Perpustakaan Online Pada SMK Negeri 1 Bojonggede Bogor" menghasilkan bahwa sistem dapat membantu pustakawan dalam penanganan sirkulasi perpustakaan, dan proses pendataan buku dapat lebih tertata dengan fasilitas penomoran buku, serta dapat mempermudah proses peminjaman dan pengembalian buku (Yusrini, Arifin, \& Yunita, 2018).

Berdasarkan penelitian yang berjudul "Design and Implementation of an ELibrary Search System" menghasilkan bahwa ketika menggunakan sistem, petugas dapat melakukan update data, hapus data, dan menambah data pada setiap entri dalam setiap kata kunci yang diterima (EROĞLU, 2014). Penelitian yang berjudul 
"Determinants of e-library services' use among university students: A study of John Harris Library, University of Benin, Nigeria" menghasilkan bahwa dengan menggunakan perpustakaan elektronik, akses ke informasi yang berkualitas akan mendorong penelitian yang berkualitas, berbagi sumber daya dan pengambilan keputusan berdasarkan informasi diantara pengguna dan pustakawan (Umukoro \& Tiamiyu, 2017). Hal yang sama diungkapkan pada penelitian yang berjudul "Effectiveness Of Digital Library: An Empirical Study" menghasilkan bahwa sekitar 58, 1 persen responden mengatakan bahwa perpustakaan digital dapat menjadi sesuatu yang bermanfaat dan dapat dimanfaatkan secara efektif (Vijayakumar, Chandrasekharendra, \& Viswa, 2016).

Berdasarkan penelitian yang berjudul "E-Library Resources and Services: Improvement and Innovation of Access and Retrieval for Effective Research Activities in University E-libraries in Kogi State Nigeria" menghasilkan bahwa untuk meningkatkan kepuasan dan kualitas dalam mengakses perpustakaan digital serta agar dapat memenuhi kebutuhan informasi, pengembangan perpustakaan digital harus mendapatkan dukungan finansial dari Kementerian Federal Pendidikan atau lembaga lain serta Universitas harus meningkatkan sumber daya dan mempekerjakan pustakawan yang berkualitas untuk memfasilitasi akses dan pengambilan informasi (Anyim, 2019).

Namun pada penelitian yang berjudul "A Web-based E-Library System for Tertiary Institutions" menyatakan bahwa sistem perpustakaan digital merupakan peningkatan luar biasa dari sistem perpustakaan tradisional karena dapat meningkatkan kegiatan pendidikan dan meminimalkan beban kerja dan waktu yang dihabiskan untuk menyimpan, mengakses, dan mengambil bahan dari perpustakaan tradisional. Selain itu penggunaan perpustakaan digital berhasil membawa kemudahan dan efisiensi daripada sistem yang sudah ada sebelumnya (Alabi Alarape \& Ndifreke Edet, 2017).

Sedangkan pada penelitian yang berjudul "Usage of a digital library system at a private university library in Bangladesh" menghasilkan bahwa penggunaan perpustakaan digital di pengaruhi oleh kemudahan penggunaan dan manfaat ketika menggunakan perpustakaan itu sendiri sehingga ketika mengadopsi perpustakaan digital harus dirancang dengan baik serta kualitas konten seperti kekayaan, keterbaharuan, kecukupan, kelengkapan penting dalam membuat perpustakaan digital (Tabassum, Roknuzzaman, \& Islam, 2015).

Digitalisasi perpustakaan juga diperlukan untuk keperluan akreditasi oleh STMIK Primakara. Hal itu dikarenakan data-data perpustakaan seperti data kunjungan perpustakaan, data koleksi pustaka, data peminjaman, dan data perpustkaan lainnya diperlukan saat dilakukan akreditasi oleh BAN-PT. Namun pada sistem yang sebelumnya hal tersebut tidak dapat dipenuhi, Selain itu, berdasarkan penelitian pendahuluan yang telah dilaksanakan didapatkan bahwa sistem yang sebelumnya memiliki tampilan yang kurang user-friendly, dan fitur 
yang sedikit.

Berdasarkan masalah tersebut, maka perlu dibuatkan sistem perpustakaan digital, Primakara Library (Prili) yang dapat memenuhi kebutuhan-kebutuhan yang diperlukan oleh Perguruan Tinggi, Pustakawan, serta Anggota Perpustakaan baik Mahasiswa, ataupun Masyarakat Umum. Pada penelitian ini pengembangan sistem akan menggunakan Framework CodeIgniter dan menggunakan metode Personal Extreme Programming (PXP). Dengan menggunakan sistem perpustakaan digital yang telah dibangun diharapkan dapat membantu dan memberikan kemudahan dalam pengelolaan data perpustakaan bagi pustakawan dan pihak Perguruan Tinggi serta dapat memudahkan anggota perpustakaan dalam mencari dan membaca koleksi pustaka yang memiliki file e-book.

\section{METODE PENELITIAN}

Metode penelitian ini dimulai dari identifikasi masalah dan studi literatur. Identifikasi masalah dilakukan dengan melakukan wawancara kepada Wakil Ketua (WAKA) I Bidang Akademik STMIK Primakara dan Mahasiswa untuk mendapatkan permasalah yang ada pada sistem sebelumnya. Untuk studi literatur dilakukan dengan membaca jurnal-jurnal yang berkaitan yang akan digunakan sebagai acuan dalam pengembangan perpustakaan digital.

Selanjutnya adalah pengembangan sistem, dalam penelitian ini digunakan metode pengembangan yaitu Personal Extreme Programming (PXP). Personal Extreme Programming (PXP) adalah suatu proses pengembangan perangkat lunak yang didesain untuk diaplikasikan oleh solo developer atau engineer (Dzhurov, Krasteva, \& Ilieva, 2009). Penggunakan metode PXP didasari oleh metode ini dapat diaplikasikan oleh solo developer serta toleransi terhadap perubahan dalam masa pengembangan sistem karena PXP sendiri merupakan modifikasi dari metode Extreme Programming (XP) yang menggunakan pendekatan Agile. Adapun Proses dalam PXP adalah proses yang berulang (iterative) yang terdiri dari beberapa proses iterasi dan siklus inline. 


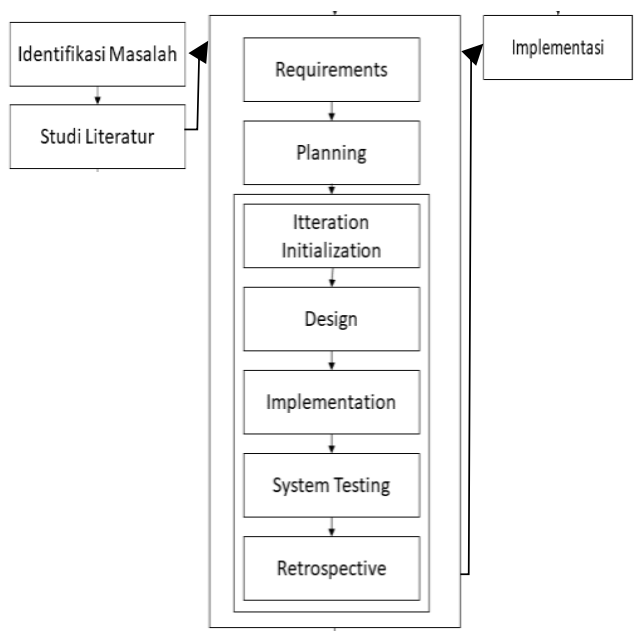

Gambar 1. Alur Penelitian

Fase pada metode pengembangan PXP dibagi menjadi beberapa proses, berikut penjelasan dari tiap prosesnya :

1) Requirements

Pada tahap ini dilakukan identifikasi kebutuhan sistem, baik itu kebutuhan fungsional maupun kebutuhan non-fungsional dan disimpan ke dalam dokumen kebutuhan. Identifikasi kebutuhan didapatkan dari hasil wawancara dengan WAKA I Bidang Akademik STMIK Primakara dan Mahasiswa STMIK Primakara serta observasi dengan melihat perpustakaan digital yang lain dan sistem yang sebelumnya. Kebutuhan dari sistem yang penulis dapatkan adalah sistem memiliki fitur untuk mendapatkan jumlah pengunjung perpustakaan, data buku yang paling banyak dibaca yang diperlukan untuk akreditasi, serta fitur history, wishlist, reward berupa TAK, dan fitur upload buku bagi mahasiswa STMIK Primakara.

2) Planning

Penulis akan membuat kumpulan tugas yang akan dilakukan berdasarkan pada dokumen kebutuhan atau dokumen kebutuhan fitur yang yang sudah dibuat.

3) Iteration Initialization

Dalam tahapan ini dimulai proses development sistem dimulai dari tugas yang menjadi fokus atau bagian yang paling penting terlebih dahulu.

4) Design

Setelah proses iterasi dimulai akan dilakukan desain database serta interface dari sistem yang dibuat.

5) Implementation

Pada tahap ini dilakukan coding, baik itu dari sisi back-end maupun front-end. Namun dalam penelitian ini tidak akan melakukan Unit Test dan hanya melakukan fase sub, Code Generation dan Code Refactor.

6) System Testing

Pada tahap ini penulis akan melakukan pengujian terhadap fungsionalitas modul sistem dengan menggunakan Blackbox Testing. 
7) Retrospective

Setelah melakukan pengujian, jika masih terdapat bug maka akan dilakukan iterasi baru pada modul yang sama, jika tidak maka akan dilanjutkan dengan membuat iterasi baru pada modul selanjutnya hingga setiap modul sistem selesai dikerjakan.

Tahap terakhir yaitu implementasi, pada tahap ini dilakukan hosting sistem serta dilakukan pengujian efektivitas sistem menggunakan metode McLean and DeLone. Penggunakan metode ini untuk mengukur kesuksesan sistem informasi karena metode ini sudah banyak digunakan dan memang didesain untuk mengukur kesuksesan sistem informai, seperti pada penelitian yang sebelumnya (Trihandayani, Aknuranda, \& Mursityo, 2018), (Agustina \& Sutinah, 2019), dan (Saputro, Budiyanto, \& Santoso, 2016). Pada McLean and Delone, ada 6 variabel yang diukut dalam model ini yaitu (Petter, Delone, \& Mclean, 2008):

1) Information Quality

Information Quality, membahas tentang kualitas informasi/output yang dihasilkan sistem. Dalam variabel ini terdapat beberapa indikator diantaranya : Completeness, Relevance, Accuracy, Timeliness, dan Format.

2) System Quality

System Quality, membahas tentang kualitas sistem baik dari segi kemudahan penggunaan dan kemudahan mempelajarinya. Dalam variabel ini terdapat beberapa indikator diantaranya : Ease of Use, Reability, Response Time, dan Flexibility.

3) Service Quality

Service Quality, membahas mengenai kualitas layanan yang diterima pengguna. Dalam variabel ini terdapat beberapa indikator diantaranya : Assurance, Empathy, dan Responsiveness

4) System Use

System Use, membahas mengenai mengenai tingkat dan cara penggunaan sistem oleh pengguna. Dalam variabel ini terdapat beberapa indikator diantaranya : Frequency of Use, dan Nature of Use.

5) User Satisfaction

User Satisfaction, membahas mengenai tingkat kepuasan pengguna terhadap sistem. Dalam variabel ini terdapat beberapa indikator diantaranya : Repeat Visit, dan Repeat Purchase

6) Net Benefit

Net Benefit, membahas mengenai dampak dan manfaat dari penggunaan sistem. Dalam variabel ini terdapat beberapa indikator diantaranya : Improve Knowledge Sharing, dan Reduce Information Search.

Pengujiannya dilakukan yaitu dengan melakukan wawancara kuisioner namun hanya kepada satu entitas yaitu mahasiswa STMIK Primakara. Untuk perhitungan sampel, penulis menggunakan rumus slovin dan dengan toleransi kesalahan sebesar 10\% yang mengacu pada penelitian (Trihandayani et al., 2018) serta 
dikarenakan waktu penelitian yang cukup singkat, maka ditemukan jumlah sampel adalah sebesar 87 responden.

$n=\frac{N}{1+N e^{2}} n=\frac{660}{1+660 *(0.1)^{2}}$

$n=\frac{660}{1+6.6} n=\frac{660}{7.6}$

$n=86.84$

Pengujian efektivitas sistem ini dilakukan untuk mendapatkan hasil apakah sistem yang telah dibuat sudah sesuai dengan kebutuhan pengguna dan sudah efektif untuk digunakan.

\section{HASIL DAN PEMBAHASAN}

\section{Bussiness Process}

Bussiness Process Peminjaman Koleksi Pustaka

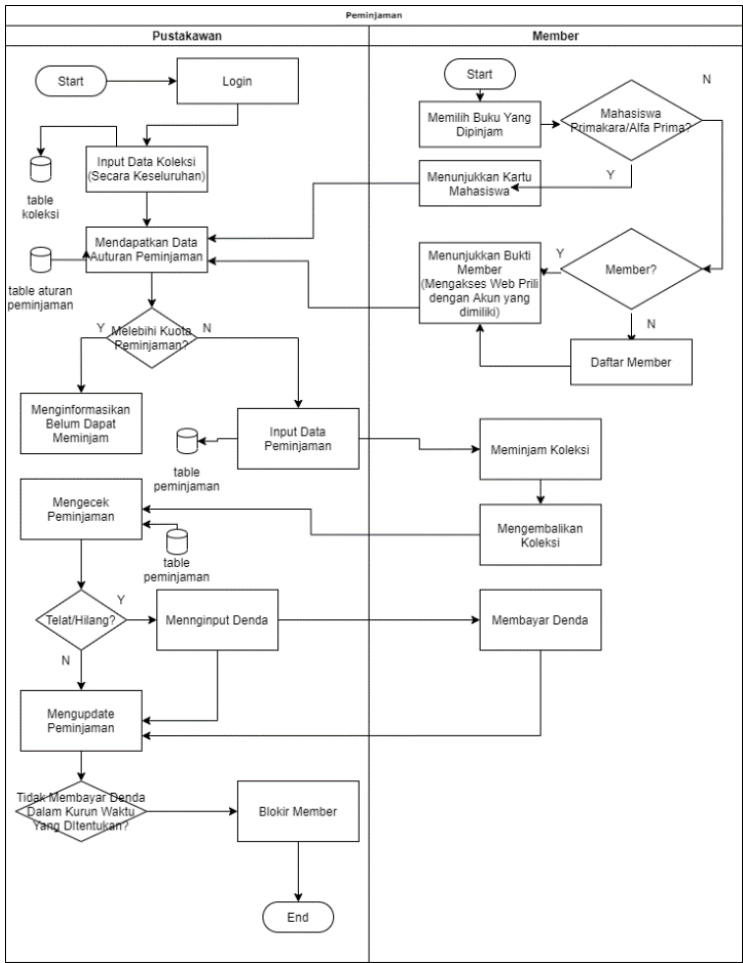

Gambar 2. Bussiness Process Peminjaman Koleksi Pustaka

Adapun penjelesan dari bussiness process peminjaman koleksi pustaka adalah sebagai berikut :

1. Pustakawan melakukan login ke Sistem, yang kemudian pustakawan menginputkan data koleksi ke sistem secara keseluruhan 
2. Mahasiswa/Anggota Perpustakaan memilih koleksi yang akan dipinjam, yang kemudian akan dicek jika peminjam belum menjadi anggota perpustakaan maka akan dilakukan pendaftaran menjadi anggota perpustakaan terlebih dahulu.

3. Pustakawan akan menginputkan data peminjaman, jika terdapat informasi bahwa peminjaman melebihi kuota peminjaman, pustakawan akan menginformasikan kepada peminjam bahwa belum dapat melakukan peminjaman untuk sementara. Jika tidak, maka peminjam dapat melakukan peminjaman koleksi

4. Kemudian saat melakukan pengembalian koleksi, pustakawan akan mengecek apakah peminjaman tersebut melewati batas waktu peminjaman atau koleksi dihilangkan. Jika iya maka pustakawan akan menginputkan denda dan menginformasikan denda, kemudian peminjam akan diminta untuk membayarkan denda.

5. Setelah itu pustakawan akan memperbaharui data peminjaman serta memperbaharui data eksemplar jika terdapat kehilangan koleksi.

Bussiness Process Pengajuan Surat Bebas Pustaka

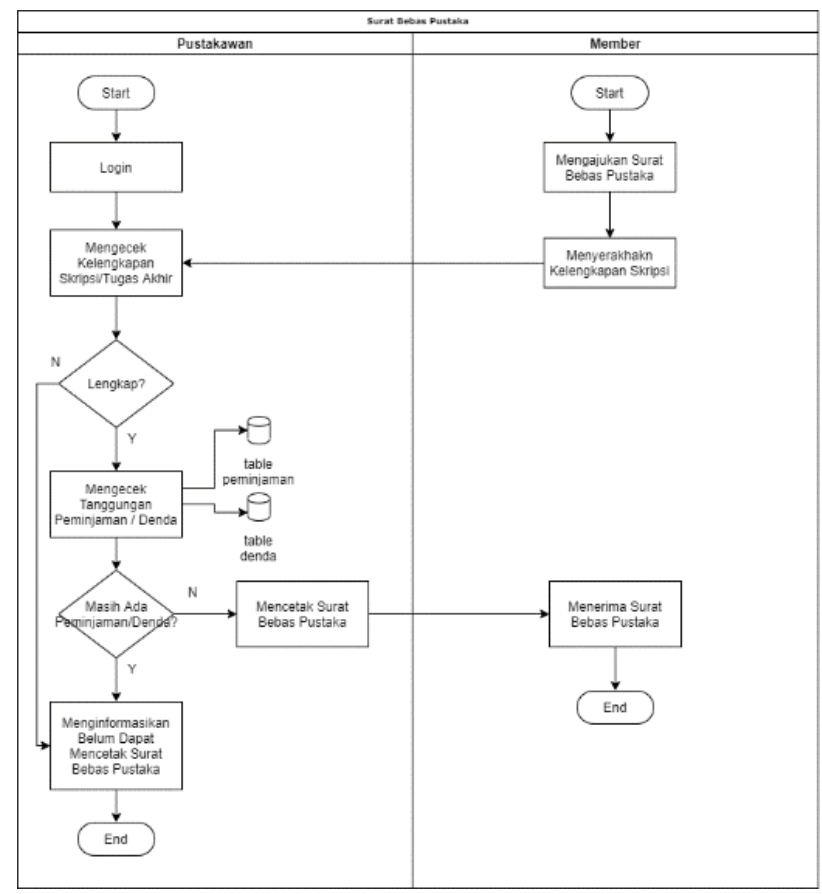

Gambar 3. Bussiness Process Surat Bebas Pustaka

Adapun penjelesan dari bussiness process pengajuan surat bebas pustaka adalah sebagai berikut : 
1. Mahasiswa mengajukan surat bebas pustaka kepada pustakawan, kemudian mahasiswa menyerahkan kelengkapan skripsi atau tugas akhir kepada pustakawan

2. Pustakawan melakukan login dan mengecek kelengkapan skripsi atau tugas akhir mahasiswa. Jika tidak lengkap, pustakawan akan menginformasikan bahwa belum dapat mencetak surat bebas pustaka saat ini sampai mahasiswa memenuhi syarat untuk mencetak surat bebas pustaka.

3. Jika lengkap maka pustakawan akan mengecek apakah mahasiswa masih memiliki tanggungan peminjaman atau denda. Jika masih memiliki tanggungan, pustakawan akan menginformasikan bahwa belum dapat mencetak surat bebas pustaka saat ini sampai mahasiswa memenuhi syarat untuk mencetak surat bebas pustaka.

4. Jika tidak memiliki tanggungan, maka pustakawan akan mencetak surat bebas pustaka dan meminta tanda tangan kepala perpustakaan yang kemudian menyerahkannya kepada mahasiswa

5. Mahasiswa akan menerima surat bebas pustaka dari pustakawan.

\section{Rancangan Sistem}

\section{Rancangan Entity Relationship Diagram}

Entity Relationship Diagram (ERD) adalah sekumpulan cara atau peralatan untuk mendeskripsikan data-data atau objek-objek yang dibuat berdasarkan dan berasal dari dunia nyata yang disebut entitas (entity) serta hubungan (relationship) antar entitas-entitas tersebut dengan menggunakan beberapa notasi (Gunawan, Wahyuni, \& Saputra, 2018). Perancangan Entity Relationship Digram diperlukan untuk memodelkan data-data pada sistem yang dimana nantinya Entity Relationship Diagram ini akan digunakan untuk membuat suatu basis data pada sistem. Berikut adalah rancangan ERD dari Perpustakaan Digital STMIK Primakara yang dapat dilihat pada gambar 4 . 


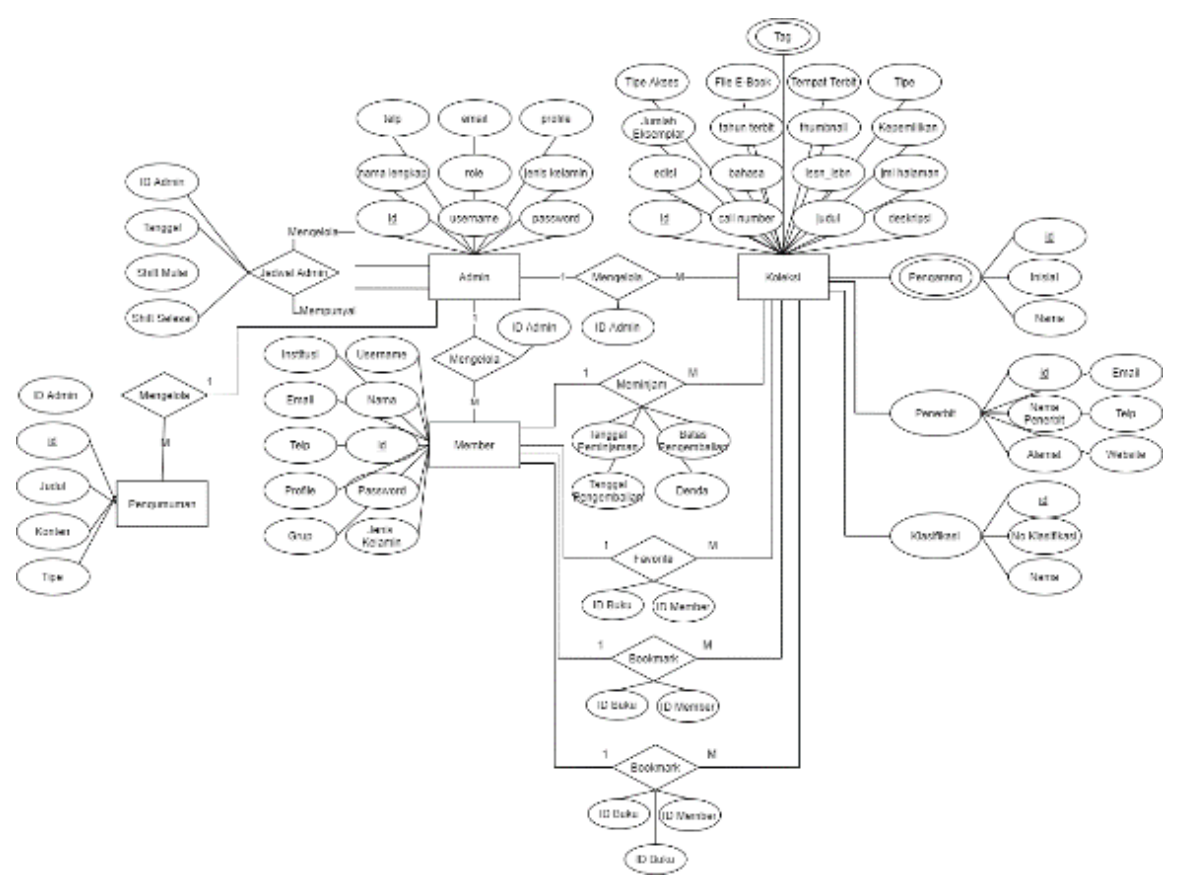

Gambar 4. Rancangan Entity Relationship Diagram (ERD)

\section{Rancangan Data Flow Diagram}

Rancangan Data Flow Diagram (DFD) digunakan untuk mengetahui aliran dari dari setiap entitas dan proses yang terjadi pada sistem. Pada penelitian ini terdapat 2 entitas yaitu Admin dan Anggota, dan berikut adalah rancangan DFD dari sistem perpustakaan digital STMIK Primakara :

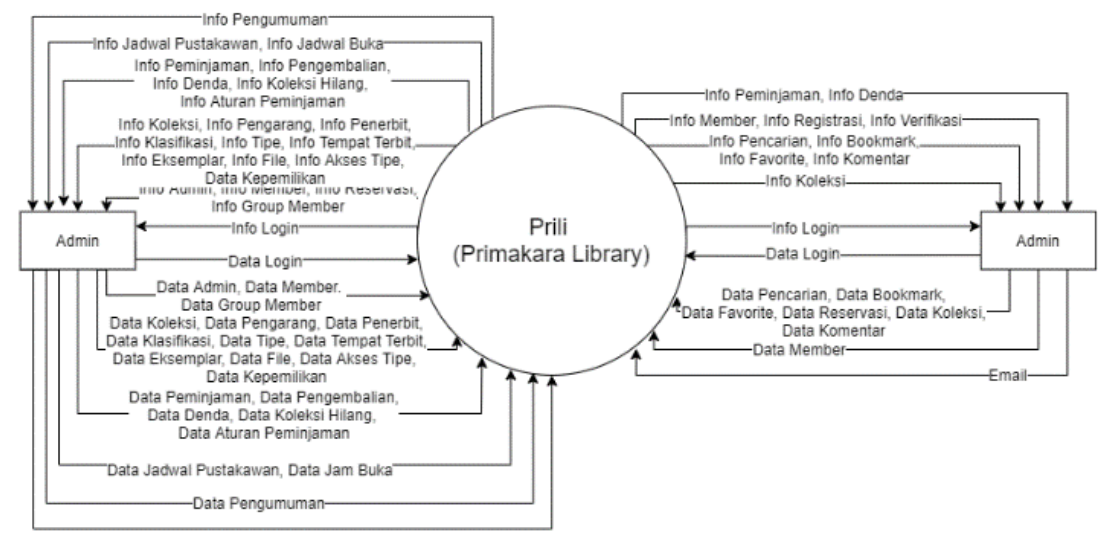

Gambar 5. Diagram Konteks

\section{User Interface Sistem}

Interface Anggota Perpustakaan

Pada kelompok halaman ini, anggota atau user dapat melihat seluruh koleksi pustaka yang dimiliki oleh STMIK Primakara, serta anggota juga dapat menyumbangkan koleksi pustaka yang mereka miliki. Jika anggota ingin membaca 
koleksi pustaka yang bersifat online, anggota harus melakukan login terlebih dahulu. Berikut adalah sebagian dari user interface pada kelompok halaman anggota perpustakaan :

1) Halaman Login

Pada halaman login, anggota memasukkan username dan password yang telah dimiliki. Jika anggota merupakan mahasiswa Primakara dapat login menggunakan akun SISKA yang telah dimiliki. Jika anggota bukan merupakan mahasiswa primakara, anggota dapat membuat akun terlebih dahulu lalu login dengan akun yang telah dibuat.

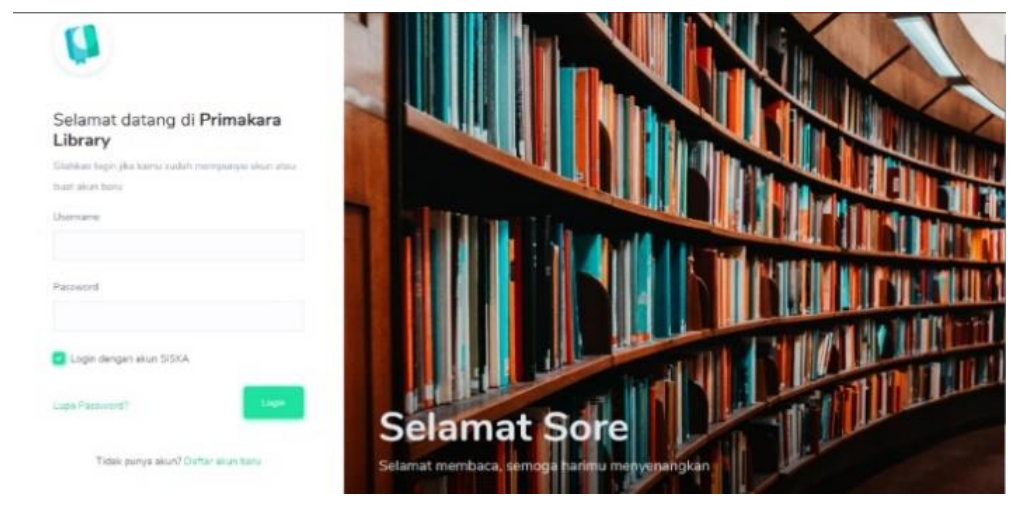

Gambar 6. User Interface Login Anggota

2) Halaman Beranda Anggota

Halaman ini adalah halaman beranda dari sistem Primakara Library, pada halaman ini anggota dapat melihat list koleksi terbaru, koleksi popular dan pengumuman yang ada di Primakara Library. Selain itu anggota dapat meng-klik salah satu menu yang ada pada sidebar untuk menuju ke halaman lain. Jika anggota meng-klik salah satu dari koleksi pustaka maka anggota akan dialihkan ke halaman detail dari koleksi pustaka tersebut dan jika anggota meng-klik sumbang koleksi maka anggota akan dialihkan ke halaman sumbang koleksi pustaka sehingga pada halaman tersebut anggota dapat menyumbangkan koleksi pustaka yang dia miliki.

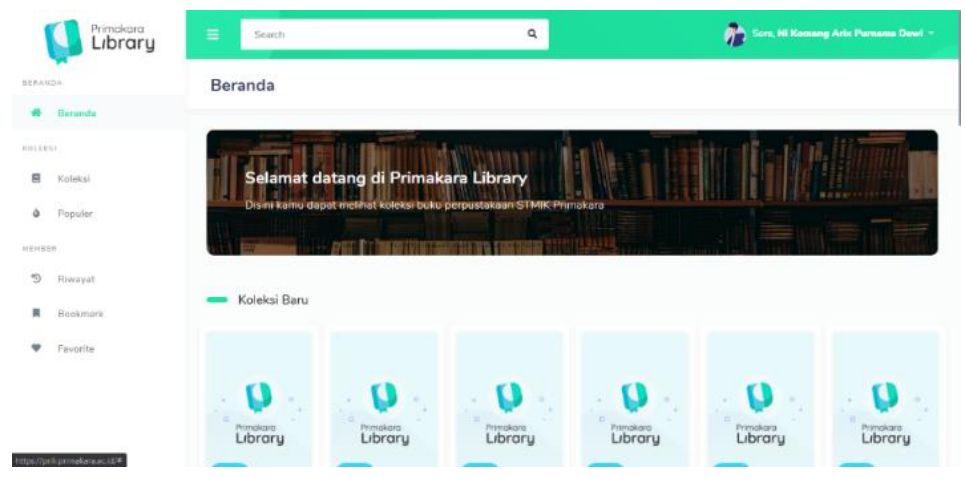

Gambar 7. User Interface Beranda Anggota 


\section{Interface Admin Perpustakaan}

Kelompok halaman ini digunakan untuk mengelola seluruh data yang ada pada perpustakaan STMIK Primakara, baik koleksi pustaka, sirkulasi koleksi, dan anggota perpustakaan. Sebelum admin dapat mengakses kelompok halaman ini admin akan diminta untuk melakukan login terlebih dahulu. Berikut adalah sebagian user interface pada kelompok halaman admin perpustakaan :

1) Halaman Dashboard

Pada halaman dashboard terdapat beberapa informasi seperti jumlah admin, jumlah koleksi, peminjaman, dan jumlah anggota. Terdapat statistik peminjaman dan statistik kunjungan baik secara bulanan sampai tahunan. Informasi mengenai peminjaman terbaru, log admin dan koleksi baru, populer, serta paling banyak dipinjam juga terdapat pada halaman ini.

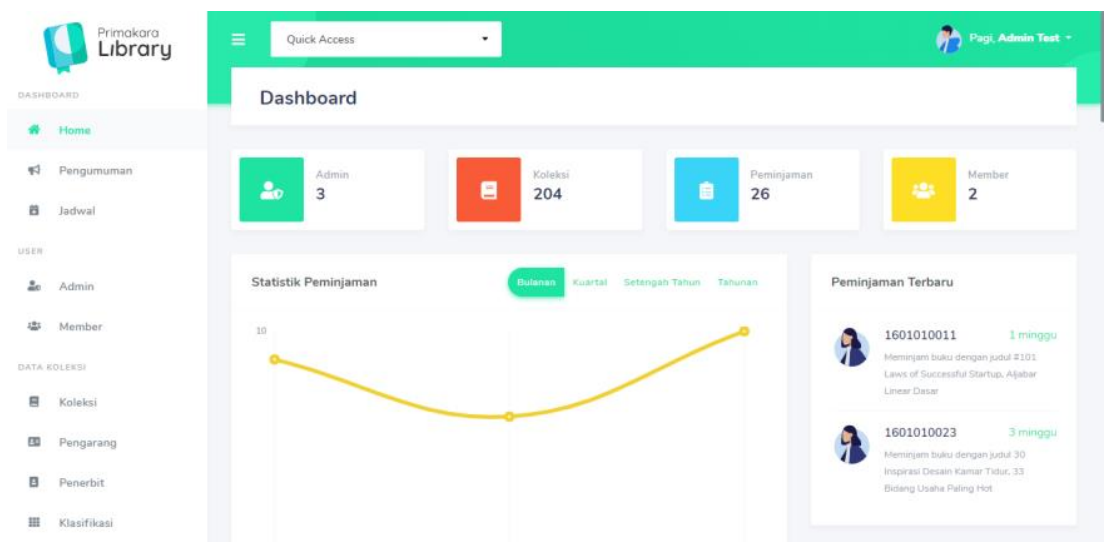

Gambar 8. User Interface Dashboard

2) Halaman Pengelolaan Koleksi Pustaka

Pada menu koleksi, admin dapat melakukan kegiatan Create, Read, Update, Delete (CRUD) koleksi pada halaman ini. Admin dapat mengunduh template import dari list koleksi seandainya admin memerlukan template input koleksi untuk dimasukkan menggunakan Aplikasi Spreadsheet, selain itu admin dapat melakukan import data untuk memasukkan data koleksi yang telah dibuat ke dalam sistem. Pada halaman ini admin juga dapat melihat atau mengelola sumbangan buku atau koleksi pustaka dari anggota. Admin juga dapat mengelolan kelengkapan koleksi pada sub menu kelengkapan koleksi. 


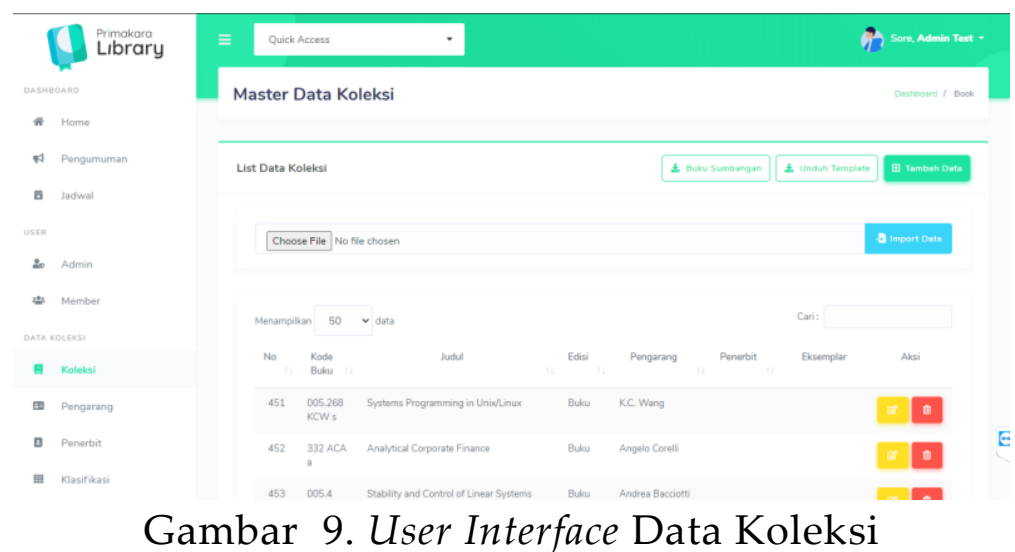

Gambar 9. User Interface Data Koleksi

3) Halaman Pengelolaan Peminjaman Koleksi

Pada menu peminjaman, admin dapat melihat list data peminjaman buku yang telah dilakukan oleh anggota, admin juga dapat melakukan tambah data peminjaman. Adapun detail dari data peminjaman dapat dilihat pada gambar dibawah.

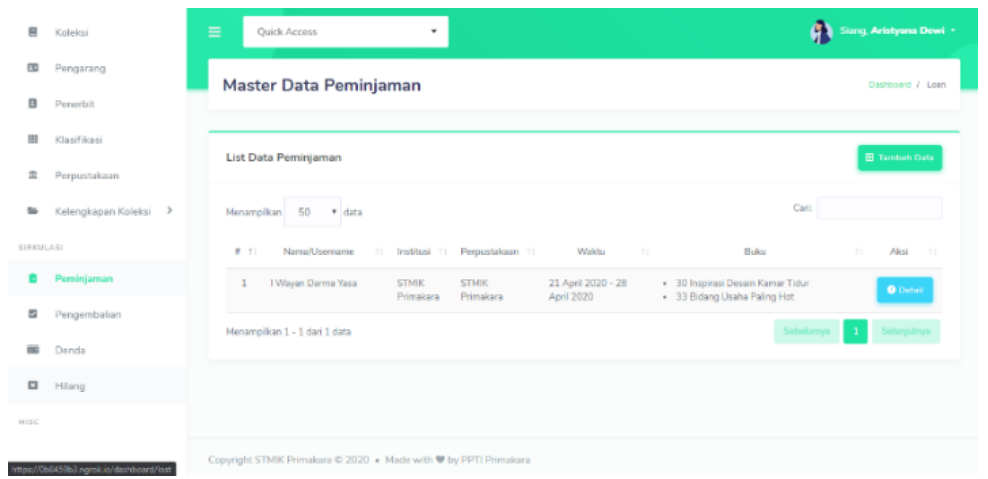

Gambar 10. User Interface Halaman Awal Data Peminjaman

Jika admin meng-klik tombol lihat, maka admin akan dialihkan ke halaman detail peminjaman. Pada detail peminjaman terdapat informasi mengenai detail peminjaman seperti, data peminjam, batas waktu peminjaman, serta sisa waktu peminjaman. Ada 3 hal yang dapat dilakukan pada halaman ini yaitu melakukan perpanjangan peminjaman, menandai kembali serta menandai hilang. Selain itu terdapat juga halaman untuk mengelola aturan peminjaman berdasarkan tipe anggota atau grup anggota.

\section{Pengujian Black Box}

Pengujian sistem ini menggunakan metode black box testing. Dimana, penulis hanya menguji fungsionalitas sistem tanpa menguji kode program dari sistem. Tahap pengujian black box, penulis gunakan untuk dapat mengetahui output dari sistem telah sesuai dengan rancangan yang telah dibuat. Berikut adalah hasil dari pengujian black box yang telah penulis lakukan : 
Halaman Anggota

Berikut adalah hasil dari pengujian black box pada entitas anggota

Tabel 1. Pengujian Black Box Halaman Anggota

\begin{tabular}{|c|c|c|c|}
\hline$\#$ & Skenario Pengujian & Hasil yang diharapkan & Kesimpulan \\
\hline \multicolumn{4}{|c|}{ Halaman Login } \\
\hline 1 & $\begin{array}{l}\text { Mengosongkan field } \\
\text { lalu klik login }\end{array}$ & $\begin{array}{l}\text { Tidak berhasil login dan ada pesan } \\
\text { error/alert }\end{array}$ & Valid \\
\hline 2 & $\begin{array}{l}\text { Mengisi field dengan } \\
\text { data akun salah }\end{array}$ & TIdak berhasil login dan ada pesan error & Valid \\
\hline 3 & $\begin{array}{l}\text { Mengisi field dengan } \\
\text { data akun benar }\end{array}$ & $\begin{array}{l}\text { Berhasil login dan masuk ke halaman } \\
\text { beranda }\end{array}$ & Valid \\
\hline \multicolumn{4}{|c|}{ Halaman Registrasi } \\
\hline 1 & $\begin{array}{l}\text { Melakukan registrasi } \\
\text { menjadi anggota }\end{array}$ & Email verifikasi terkirim & Valid \\
\hline 2 & Verifikasi & Status anggota berubah menjadi aktif & Valid \\
\hline \multicolumn{4}{|c|}{ Halaman Forgot Password } \\
\hline 1 & $\begin{array}{l}\text { Melakukan forgot } \\
\text { password }\end{array}$ & $\begin{array}{l}\text { Email dengan link untuk reset password } \\
\text { terkirim }\end{array}$ & Valid \\
\hline 2 & Verifikasi & Masuk ke halaman reset password & Valid \\
\hline 3 & Reset password & Password berhasil diganti & Valid \\
\hline \multicolumn{4}{|c|}{ Menu Sidebar } \\
\hline 1 & Klik koleksi & $\begin{array}{l}\text { Masuk ke halaman koleksi dan melihat } \\
\text { seluruh koleksi Primakara Library }\end{array}$ & Valid \\
\hline 2 & Klik pengumuman & $\begin{array}{l}\text { Masuk ke halaman pengumuman dan } \\
\text { melihat seluruh pengumuman } \\
\text { Primakara Library }\end{array}$ & Valid \\
\hline 3 & Klik popular & $\begin{array}{l}\text { Masuk ke halaman koleksi popular dan } \\
\text { melihat } 50 \text { koleksi popular Primakara } \\
\text { Library }\end{array}$ & Valid \\
\hline 4 & Klik menu riwayat & $\begin{array}{l}\text { Masuk ke halaman riwayat dan dapat } \\
\text { melihat riwayat bacaan dan kunjungan } \\
\text { user }\end{array}$ & Valid \\
\hline 5 & Klik menu peminjaman & $\begin{array}{l}\text { Masuk ke halaman riwayat peminjaman } \\
\text { dan melihat daftar koleksi yang pernah } \\
\text { dipinjam }\end{array}$ & Valid \\
\hline 6 & Klik menu bookmark & $\begin{array}{l}\text { Masuk ke halaman bookmark dan melihat } \\
\text { daftar koleksi yang di-bookmark }\end{array}$ & Valid \\
\hline 7 & Klik menu favorite & $\begin{array}{l}\text { Masuk ke halaman favorite dan melihat } \\
\text { daftar koleksi yang ditandai sebagai } \\
\text { favorite }\end{array}$ & Valid \\
\hline \multicolumn{4}{|c|}{ Pencarian } \\
\hline 1 & Cari menggunakan & Menampilkan hasil pencarian, jika tidak & Valid \\
\hline
\end{tabular}




\begin{tabular}{|l|l|l|l|}
\hline & kolom pencarian & $\begin{array}{l}\text { ada menampilkan pesan koleksi tidak } \\
\text { ada }\end{array}$ & \\
\hline 2 & $\begin{array}{l}\text { Cari menggunakan } \\
\text { advance search }\end{array}$ & $\begin{array}{l}\text { Menampilkan hasil pencarian } \\
\text { berdasarkan filter yang telah diisi }\end{array}$ & Valid \\
\hline \multicolumn{2}{|l|}{ Detail Koleksi } \\
\hline 1 & Klik link detail koleksi & $\begin{array}{l}\text { Masuk ke halaman detail koleksi, } \\
\text { menambahkan kedalam daftar riwayat } \\
\text { dan menampilkan detail koleksi }\end{array}$ & Valid \\
\hline 4 & Klik baca sekarang & $\begin{array}{l}\text { Masuk ke halaman baca buku dan } \\
\text { menambahkan ke dalam daftar riwayat } \\
\text { bacaan }\end{array}$ & Valid \\
\hline 1 & $\begin{array}{l}\text { Klik salah } \\
\text { pengumuman }\end{array}$ & $\begin{array}{l}\text { Masuk ke halaman detail pengumuman } \\
\text { dan menampilkan detail pengumuman }\end{array}$ & Valid \\
\hline Profile & $\begin{array}{l}\text { Masuk ke halaman profile dan melihat } \\
\text { jumlah bacaan, peminjaman, denda, dan } \\
\text { fom update profile }\end{array}$ & Valid \\
\hline 1 & Klik profile & Profile member terupdate & Valid \\
\hline
\end{tabular}

\subsubsection{Halaman Admin}

Berikut adalah hasil dari pengujian black box pada entitas admin

Tabel 2. Pengujian Black Box Halaman Admin

\begin{tabular}{|c|c|c|c|}
\hline No. & $\begin{array}{c}\text { Skenario } \\
\text { Pengujian }\end{array}$ & Hasil yang diharapkan & Kesimpulan \\
\hline \multicolumn{4}{|c|}{ Halaman Login } \\
\hline 1 & $\begin{array}{l}\text { Mengosongkan } \\
\text { field lalu klik Login }\end{array}$ & $\begin{array}{l}\text { Tidak berhasil login dan ada pesan } \\
\text { error/alert }\end{array}$ & Valid \\
\hline 2 & $\begin{array}{l}\text { Mengisi field } \\
\text { dengan data akun } \\
\text { salah }\end{array}$ & $\begin{array}{l}\text { TIdak berhasil login dan ada pesan } \\
\text { error }\end{array}$ & Valid \\
\hline 3 & $\begin{array}{l}\text { Mengisi field } \\
\text { dengan data akun } \\
\text { benar }\end{array}$ & $\begin{array}{l}\text { Berhasil login dan masuk ke } \\
\text { halaman dashboard }\end{array}$ & Valid \\
\hline \multicolumn{4}{|c|}{ Halaman Dashboard } \\
\hline 1 & Klik dashboard & $\begin{array}{l}\text { Masuk ke halaman dashboard } \\
\text { Menampilkan jumlah admin, } \\
\text { member, koleksi, peminjaman, } \\
\text { statistik peminjaman dan } \\
\text { kunjungan, daftar buku popular } \\
\text { dan terbaru, log admin, } \\
\text { peminjaman terbaru, dan login hari }\end{array}$ & Valid \\
\hline
\end{tabular}




\begin{tabular}{|c|c|c|c|}
\hline & & ini & \\
\hline \multicolumn{4}{|c|}{ Halaman Pengumuman } \\
\hline 1 & $\begin{array}{l}\text { Klik menu } \\
\text { pengumuman }\end{array}$ & $\begin{array}{l}\text { Masuk ke halaman halaman awal } \\
\text { pengumuman dan menampilkan } \\
\text { daftar pengumuman }\end{array}$ & Valid \\
\hline 2 & Menambahkan data & $\begin{array}{l}\text { Data berhasil ditambahkan jika } \\
\text { data yang diperlukan lengkap }\end{array}$ & Valid \\
\hline 3 & Mengedit data & $\begin{array}{l}\text { Data berhasil diperbaharui jika } \\
\text { data yang diperlukan lengkap }\end{array}$ & Valid \\
\hline 4 & Menghapus data & Data berhasil terhapus & Valid \\
\hline \multicolumn{4}{|c|}{ Halaman Data Admin } \\
\hline 1 & $\begin{array}{l}\text { Akses dengan akun } \\
\text { administrator }\end{array}$ & Tidak dapat mengakses & Valid \\
\hline 2 & $\begin{array}{l}\text { Akses dengan akun } \\
\text { super administrator }\end{array}$ & $\begin{array}{l}\text { Dapat mengakses dan melihat } \\
\text { daftar admin }\end{array}$ & Valid \\
\hline 3 & $\begin{array}{l}\text { Mengakses } \\
\text { halaman awal } \\
\text { admin }\end{array}$ & Menampilkan daftar admin & Valid \\
\hline 4 & $\begin{array}{l}\text { Menambah data } \\
\text { admin }\end{array}$ & $\begin{array}{l}\text { Data admin berhasil ditambahkan } \\
\text { dan masuk ke database }\end{array}$ & Valid \\
\hline 5 & $\begin{array}{l}\text { Mengedit data } \\
\text { admin }\end{array}$ & $\begin{array}{l}\text { Data admin berhasil diperbaharui } \\
\text { dan data dalam database berubah }\end{array}$ & Valid \\
\hline 6 & $\begin{array}{l}\text { Menghapus data } \\
\text { admin }\end{array}$ & Data admin terhapus & Valid \\
\hline \multicolumn{4}{|c|}{ Halaman Data Member } \\
\hline 1 & $\begin{array}{l}\text { Mengakses } \\
\text { halaman awal } \\
\text { member }\end{array}$ & Menampilkan daftar member & Valid \\
\hline 2 & $\begin{array}{l}\text { Menambah data } \\
\text { member }\end{array}$ & $\begin{array}{l}\text { Data member berhasil ditambahkan } \\
\text { dan masuk ke database }\end{array}$ & Valid \\
\hline 3 & $\begin{array}{l}\text { Mengedit data } \\
\text { member }\end{array}$ & $\begin{array}{l}\text { Data member berhasil diperbaharui } \\
\text { dan data dalam database berubah }\end{array}$ & Valid \\
\hline 4 & $\begin{array}{l}\text { Menghapus data } \\
\text { member }\end{array}$ & Data member terhapus & Valid \\
\hline 5 & Klik blokir & $\begin{array}{l}\text { Member berstatus blokir atau } \\
\text { unblock }\end{array}$ & Valid \\
\hline 6 & $\begin{array}{l}\text { Mencetak surat } \\
\text { bebas pustaka }\end{array}$ & $\begin{array}{l}\text { Surat berhasil dicetak jika tidak ada } \\
\text { tanggungan peminjaman dan } \\
\text { denda }\end{array}$ & Valid \\
\hline
\end{tabular}




\begin{tabular}{|c|c|c|c|}
\hline 7 & Klik member group & Masuk ke halaman group member & Valid \\
\hline \multicolumn{4}{|c|}{ Halaman Koleksi } \\
\hline 1 & $\begin{array}{l}\text { Mengakses } \\
\text { halaman awal } \\
\text { koleksi }\end{array}$ & $\begin{array}{l}\text { Menampilkan daftar koleksi } \\
\text { pustaka }\end{array}$ & Valid \\
\hline 2 & $\begin{array}{l}\text { Menambah data } \\
\text { koleksi pustaka }\end{array}$ & $\begin{array}{l}\text { Data koleksi berhasil ditambahkan } \\
\text { dan masuk ke database }\end{array}$ & Valid \\
\hline 3 & $\begin{array}{l}\text { Mengedit data } \\
\text { koleksi pustaka }\end{array}$ & $\begin{array}{l}\text { Data koleksi berhasil diperbaharui } \\
\text { dan data dalam databse berubah }\end{array}$ & Valid \\
\hline 4 & $\begin{array}{l}\text { Menghapus data } \\
\text { koleksi }\end{array}$ & Data terhapus secara soft delete & Valid \\
\hline 5 & $\begin{array}{l}\text { Mengunduh } \\
\text { template import }\end{array}$ & Template import berhasil diunduh & Valid \\
\hline 6 & $\begin{array}{l}\text { Mengimport data } \\
\text { koleksi }\end{array}$ & $\begin{array}{l}\text { Data koleksi berhasil masuk ke } \\
\text { database }\end{array}$ & Valid \\
\hline \multicolumn{4}{|c|}{ Halaman peminjaman } \\
\hline 1 & $\begin{array}{l}\text { Mengakses } \\
\text { halaman awal } \\
\text { peminjaman }\end{array}$ & $\begin{array}{l}\text { Menampilkan daftar peminjaman } \\
\text { aktif }\end{array}$ & Valid \\
\hline 2 & $\begin{array}{l}\text { Menambah data } \\
\text { peminjaman }\end{array}$ & $\begin{array}{l}\text { Data peminjaman berhasil } \\
\text { ditambahkan dan masuk ke } \\
\text { database }\end{array}$ & Valid \\
\hline 3 & $\begin{array}{l}\text { Memperbaharui } \\
\text { status peminjaman }\end{array}$ & $\begin{array}{l}\text { Data peminjaman berhasil } \\
\text { diperbaharui dan data dalam } \\
\text { databse berubah }\end{array}$ & Valid \\
\hline 4 & $\begin{array}{l}\text { Menambah data } \\
\text { pinjaman jika kuota } \\
\text { penuh }\end{array}$ & $\begin{array}{l}\text { Tidak dapat melakukan } \\
\text { peminjaman }\end{array}$ & Valid \\
\hline 5 & $\begin{array}{l}\text { Melihat detail } \\
\text { pinjaman }\end{array}$ & $\begin{array}{l}\text { Masuk ke halaman detail } \\
\text { peminjaman dan menampilkan } \\
\text { informasi peminjaman }\end{array}$ & Valid \\
\hline 6 & $\begin{array}{l}\text { Klik peraturan } \\
\text { peminjaman }\end{array}$ & $\begin{array}{l}\text { Masuk ke halaman peraturan } \\
\text { peminjaman dan menampilkan list } \\
\text { peraturan peminjaman }\end{array}$ & Valid \\
\hline \multicolumn{4}{|c|}{ Halaman pengembalian } \\
\hline 1 & $\begin{array}{l}\text { Mengakses } \\
\text { halaman awal } \\
\text { pengembalian }\end{array}$ & Menampilkan daftar pengembalian & Valid \\
\hline 2 & Melihat detail & Masuk ke halaman & Valid \\
\hline
\end{tabular}




\begin{tabular}{|l|l|l|l|}
\hline & pinjaman & $\begin{array}{l}\text { pengembalian dan menampilkan } \\
\text { informasi pengembalian }\end{array}$ & \\
\hline Halaman denda & $\begin{array}{l}\text { Mengakses } \\
\text { halaman awal } \\
\text { denda }\end{array}$ & $\begin{array}{l}\text { Menampilkan daftar denda } \\
\text { aktif/blm dibayar }\end{array}$ & Valid \\
\hline 2 & $\begin{array}{l}\text { Memperbaharui } \\
\text { status denda }\end{array}$ & $\begin{array}{l}\text { Data denda berhasil diperbaharui } \\
\text { dan data dalam databse berubah }\end{array}$ & Valid \\
\hline 3 & $\begin{array}{l}\text { Melihat detail } \\
\text { pinjaman }\end{array}$ & $\begin{array}{l}\text { Masuk ke halaman detail denda } \\
\text { dan menampilkan informasi denda }\end{array}$ & Valid \\
\hline 4 & Klik estimasi denda & $\begin{array}{l}\text { Masuk ke halaman estimasi denda } \\
\text { dan melihat peminjaman yang } \\
\text { sudah melewati batas waktu dan } \\
\text { estimasi denda }\end{array}$ & Valid \\
\hline 1 & Mengakses profile & $\begin{array}{l}\text { Menampilkan detail admin } \\
\text { profile }\end{array}$ & $\begin{array}{l}\text { Profile Admin berhasil } \\
\text { diperbaharui }\end{array}$ \\
\hline 2 & Valid \\
\hline
\end{tabular}

\section{Uji Efektivitas Sistem}

Uji Efektivitas ini hanya dilakukan kepada subjek mahasiswa STMIK Primakara. Responden yang mengisi kuisioner adalah sebanyak 93 responden. Responded terbanyak adalah mahasiswa angkatan 2016 sebanyak 31,25\% diikuti mahasiswa angkatan 2017 sebanyak 23,7\%, mahasiswa angkatan 2018 sebanyak 22,65\%, mahasiswa angkatan 2019 sebanyak 21,5\%, dan mahasiswa angkatan 2015 sebanyak $1,1 \%$. Penilaian pada kuisioner ini menggunakan skala dari 1-4 dan berikut adalah hasil penilaian yang penulis dapat dari hasil kuisioner yang telah disebar, adalah sebagai berikut:

Tabel 3. Hasil Kuisioner Uji Efektivitas McLean and DeLone

\begin{tabular}{|c|c|c|}
\hline Indikator & Total & Skor \\
\hline \multicolumn{2}{|c|}{ Variabel System Quality } & 3.33 \\
\hline Ease of Use & 319 & 3.43 \\
\hline Reability & 279 & 3.0 \\
\hline Response Time & 303 & 3.25 \\
\hline Flexibility & 339 & 3.64 \\
\hline
\end{tabular}




\begin{tabular}{|l|l|l|}
\hline Variabel Information Quality & 3.08 \\
\hline Completeness & 271 & 2.9 \\
\hline Relevance & 279 & 2.99 \\
\hline Accuracy & 289 & 3.11 \\
\hline Timeliness & 283 & 3.04 \\
\hline Format & 315 & 3.38 \\
\hline Variabel Service Quaility & & 3.28 \\
\hline Assurance & 317 & 3.4 \\
\hline Empathy & 295 & 3.16 \\
\hline Responsiveness & 305 & 3.27 \\
\hline Variabel System Use & & $\mathbf{2 . 3 5}$ \\
\hline Frequency of Use & 203 & 2.18 \\
\hline Nature of Use & 234 & 2.52 \\
\hline Variabel User Satisfaction & & 3.18 \\
\hline Repeat Visit & 291 & 3.13 \\
\hline Repeat Purchase & 302 & 3.24 \\
\hline Variabel Net Benefit & & 3.26 \\
\hline Improve Knowledge Sharing & 301 & 3.23 \\
\hline Reduce Information Search & 306 & 3.28 \\
\hline
\end{tabular}

Berdasarkan keseluruhan dari hasil penilaian pada seluruh variabel uji efektivitas menggunakan metode McLean and DeLone, dapat disimpulkan bahwa sistem Primakara Library yang telah dibangun sudah memiliki tingkat kesuksesan atau efektivitas yang cukup baik. Namun masih perlu untuk ditingkatkan lagi, dapat dengan menambah data koleksi pustaka serta lebih mensosialisasikan lagi sistem ini kepada mahasiswa agar penilaian pada variabel system use, karena penilaian pada variabel ini masih sangat kurang.

\section{KESIMPULAN}

Berdasarkan seluruh pembahasan yang telah penulis uraikan, maka dapat ditarik kesimpulan pada penelitian ini yaitu:

1. Perancangan dan pengembangan sistem perpustakaan digital STMIK Primakara menggunakan framework CodeIgniter telah selesai dilakukan. Pengguna dari sistem ini ada 2 yaitu Pustakawan dan Anggota Perpustakaan. Fitur yang terdapat pada sistem ini pada sisi Admin adalah pengelolaan koleksi pustaka, pengelolaan data pengguna, serta pengelolaan sirkulasi pustaka, dan statistik kunjungan serta peminjaman yang ada pada bagian dashboard. Sedangkan pada sisi Anggota, fiturnya adalah login menggunakan akun SISKA Primakara, fitur riwayat, favorite, bookmark, serta 
baca buku online. Pengembangan dengan menggunakan metode Personal Extreme Programming (PXP) dapat membantu mengembangkan salah satu fitur terlebih dahulu jika ada kebutuhan fitur yang mendesak untuk di kembangkan namun dengan syarat fitur tersebut harus fitur yang tidak memerlukan fitur lainnya untuk dapat digunakan.

2. Berdasarkan hasil dari uji efektivitas sistem menggunakan metode McClean and Delone, didapat hasil penilaian diantaranya variabel system quality sebesar 3.33, variabel information quality sebesar 3.08, variabel service quality sebesar 3.28, variabel system use sebesar 2.35, variabel user satisfaction sebesar 3.13, dan variabel net benefit sebesar 3.26. Dari hasil tersebut dapat disimpulkan bahwa sistem yang telah dibangun memiliki tingkat kesuksesan yang cukup baik.

\section{DAFTAR PUSTAKA}

Agustina, N., \& Sutinah, E. (2019). Model Delone dan McLean Untuk Menguji Kesuksesan Aplikasi Mobile Penerimaan Mahasiswa Baru. InfoTekJar (Jurnal Nasional Informatika Dan Teknologi Jaringan), 3(2), 76-82. https://doi.org/10.30743/infotekjar.v3i2.1008

Alabi Alarape, M., \& Ndifreke Edet, S. (2017). A Web-based E-Library System for Tertiary Institutions. International Journal of Applied Information Systems, 12(2), 17-22. https://doi.org/10.5120/ijais2017451685

Anyim, W. O. (2019). E-library resources and services: Improvement and innovation of access and retrieval for effective research activities in university e-libraries in Kogi State Nigeria. Library Philosophy and Practice, 2019(February).

Budihartanti, C., Tuslaela, \& Aeni, E. N. (2019). Sistem Informasi Perpustakaan Online ( E-Library ) Pada MTs AL Maghfiroh Pekayon. 4(2), 245-250.

Dzhurov, Y., Krasteva, I., \& Ilieva, S. (2009). Personal Extreme Programming-An Agile Process for Autonomous Developers. International Conference on Software, Services \& Semantic Technologies, (August 2016), 252-259. Retrieved from https://www.researchgate.net/publication/229046039_Personal_Extreme_Prog ramming-An_Agile_Process_for_Autonomous_Developers

EROĞLU, H. H. (2014). Design and Implementation of an Autonomous. Ekp, 13(January), 576.

Gunawan, A., Wahyuni, N., \& Saputra, B. K. (2018). Perancangan Sistem Informasi Penugasan Dosen Berbasis Website Pada Jurusan Teknik Industri FT Untirta. 1, 7680.

Indonesia. (2007). Undang-Undang No. 43 Tahun 2007 tentang Perpustakaan. Jakarta: Sekretariat Negara.

Nugraha, F. (2014). Analisa Dan Perancangan Sistem Informasi Perpustakaan. SIMETRIS, 5(18), 1-10. 
Petter, S., Delone, W., \& Mclean, E. (2008). Measuring information systems success : models, dimensions, measures, and interrelationships. (December 2006), 236-263. https://doi.org/10.1057/ejis.2008.15

Putri, S. I., \& S, Y. A. (2016). Perancangan Sistem Perpustakaan Online Menggunakan Metode Model View Controller ( MVC ) Studi Kasus STMIK Asia Malang. 10(2), 1723.

Saputro, P. H., Budiyanto, D., \& Santoso, J. (2016). Model Delone and Mclean Untuk Mengukur Kesuksesan E-Government Kota Pekalongan. Scientific Journal of Informatics, 2(1), 1-8. https://doi.org/10.15294/sji.v2i1.4523

Tabassum, M., Roknuzzaman, M., \& Islam, M. M. (2015). Usage of a digital library system at a private university library in Bangladesh. Annals of Library and Information Studies, 62(2), 94-103.

Trihandayani, L. H., Aknuranda, I., \& Mursityo, Y. T. (2018). Penerapan Model Kesuksesan Delone dan Mclean pada Website Fakultas Ilmu Komputer ( FILKOM ) Universitas Brawijaya. Jurnal Pengembangan Teknologi Informasi Dan Ilmu Komputer (J-PTIIK) Universitas Brawijaya, 2(12).

Umukoro, I. O., \& Tiamiyu, M. A. (2017). Determinants of e-library services' use among university students: A study of John Harris Library, University of Benin, Nigeria. Journal of Librarianship and Information Science, 49(4), 438-453. https://doi.org/10.1177/0961000616653176

Vijayakumar, S., Chandrasekharendra, S., \& Viswa, S. (2016). EFFECTIVENESS OF DIGITAL LIBRARY : AN EMPIRICAL STUDY. International Journal of Library $\mathcal{E}$ Information Science, 5(3), 119-132.

Wahyudi, A. (2018). Pengembangan Perpustakaan Digital Bebasis Android Dengan $\begin{array}{lllll}\text { Metode Scrum. Faktor Exacta, } 11(2), & 128 .\end{array}$ https://doi.org/10.30998/faktorexacta.v11i2.2484

Yusrini, D., Arifin, Y. T., \& Yunita, N. (2018). Perancangan Dan Pengembangan Sistem Informasi Perpustakaan Online Pada SMK Negeri 1 Bojonggede Bogor. XX(1), 13-20. 